\title{
Orgeldispositioner fra Sønderborg amt
}

\author{
Af Else-Marie Boyhus.
}

Af kirkeinventar er orglerne vel det mest forgængelige; façaderne kan stá igennem lange tider, men selve værket er udsat for tidernes skiften. Thi et orgel er ikke blot en prydgenstand, men et instrument, hvis mekanik gennem brugen slides og derfor må fornyes. Tilmed er orglerne $i$ allerhøjeste grad underkastet moden: Da højbarokkens instrumentbygning slog igennem, blev renaissanceorglerne udskiftet, og da den romantiske musik $i$ forrige ârhundrede bragte nye klangidealer, blev de barokke orgler i stor udstrækning of ret; og nu i 20. århundrede, hvor man er vendt tilbage til de barokke forbilleder, fares der frem med hård hånd mod de romantiske instrumenter. Derfor kan orgelhistorien kun i forsvindende få tilfælde støtte sig til en undersøgelse af intakte instrumenter; bevarede orgler, der er over 100 år gamle, kan hurtigt opregnes i Danmark. Orgelhistorikeren er derfor henvist til arkivstudier; men da kilderne til belysning af orglets udvikling ligger spredt og godt gemt $i$ kirkernes arkiver, er Danmarks orgelhistorie endnu ret unuanceret.

Et stort initiativ er taget af Niels Friis, der i sin bog "Orgelbygning i Danmark " fra 1949 gennemgår de større orgler og orgelbyggere fra ca. 1550 til ca. 1790; men endnu mangler en samlende undersogelse af romantikkens tidsalder, også en rig, men desvarre alt for overset periode.

Det spredte kildemateriale forklarer, at landsbykirkernes orgler kun undtagelsesvis er behandlet; hertil kommer, at emnet $i$ sig selv ikke er så umiddelbart tillokkende som de store instrumenter, idet landsbykirkeorglerne på ingen måde har skabt epoke i historien. Forst nu, hvor Niels Friis i sin bog har redegjort for de store linier, er det frugtbart at udbygge hans billede ved at skrive orgelhistorie ikke blot kronologisk men også topografisk. En systematisk gennemgang af kirkearkivalierne for Søn- 
derborg amt ${ }^{1}$ er således grundlaget for nærværende redegørelse.

Et af den danske orgelhistories store problemer er, hvor tidligt fik landsbykirkerne orgler? En besvarelse af dette spørgsmål kan kun en nøje gennemgang af samtlige kirkers arkiver give. Som helhed kan man dog næppe regne med, at de danske landsbykirker får orgler før i løbet af 18.-19. århundrede; men i de rigeste egne kan man træffe orgler så langt tilbage $i$ tiden som 16. århundrede. Dette er netop tilfældet i Sonderborg amt.

Så tidligt som i 1591 omtaler Broager kirkes regnskabsbog' planer om at anskaffe et nyt orgel. Nu behøver ordet nyt ikke at indebære, at der tidligere har været et instrument i kirken; men det er dog ikke usandsynligt, når man tager den statelige kirkes menighed i betragtning. Den bestod for en del af velhavende skippere, der stod $\mathrm{i}$ jævnlig forbindelse med Nordtyskland og dermed med et af orgelbygningens centre.

1592 realiseredes planerne, og mester Joachim Willers byggede det nye orgel til kirken. Der har næppe været tale om noget stort instrument, idet udgifterne til dette og en ny døbefont kun beløb sig til 218 mark. Først 1668 har vi orglets disposition ${ }^{3}$ optegnet; det bestod da af et værk med følgende seks stemmer: Principal, oktav, mixtur, $\gg$ Mittelmässig " gedakt, fløjte og regal. En meget almindelig opbygning af et lille instrument, med de tre første registre som principalkor, gedakten og fløjten som repræsentanter for de blidere stemmer, og endelig den af renaissancen så yndede tungestemme: Regal. Hvor nær dette kommer originaldispositionen fra 1592 er umuligt at sige, idet orglet mellem 1592 og 1668 blev repareret ialt 5 gange 4 , 1635 var der tilmed tale om en hovedreparation, hvad der blev foretaget ved denne lejlighed er ikke overleveret; det vides kun, at der blev købt materialer til istandsættelse af bælgen, men den samlede reparationsudgift på 166 mark tilkendegiver, at også andre dele af instrumentet må være berørt af reparationen.

Orgelbygger Joachim Willers optræder igen i 1604, denne gang i Sonderborg, hvor han skulle levere orglet til den nyopførte sognekirke her. Han stammede fra Salzwedel i nærheden af Lübeck, og han har formentlig lært sit håndværk $\mathrm{i}$ denne by, hvor de rige orgelbygningstraditioner stadig levede ${ }^{\mathrm{s}}$. I Danmark mødes han første gang i 1592 i Broager; 1607 reparerede han orglet i Vejles 


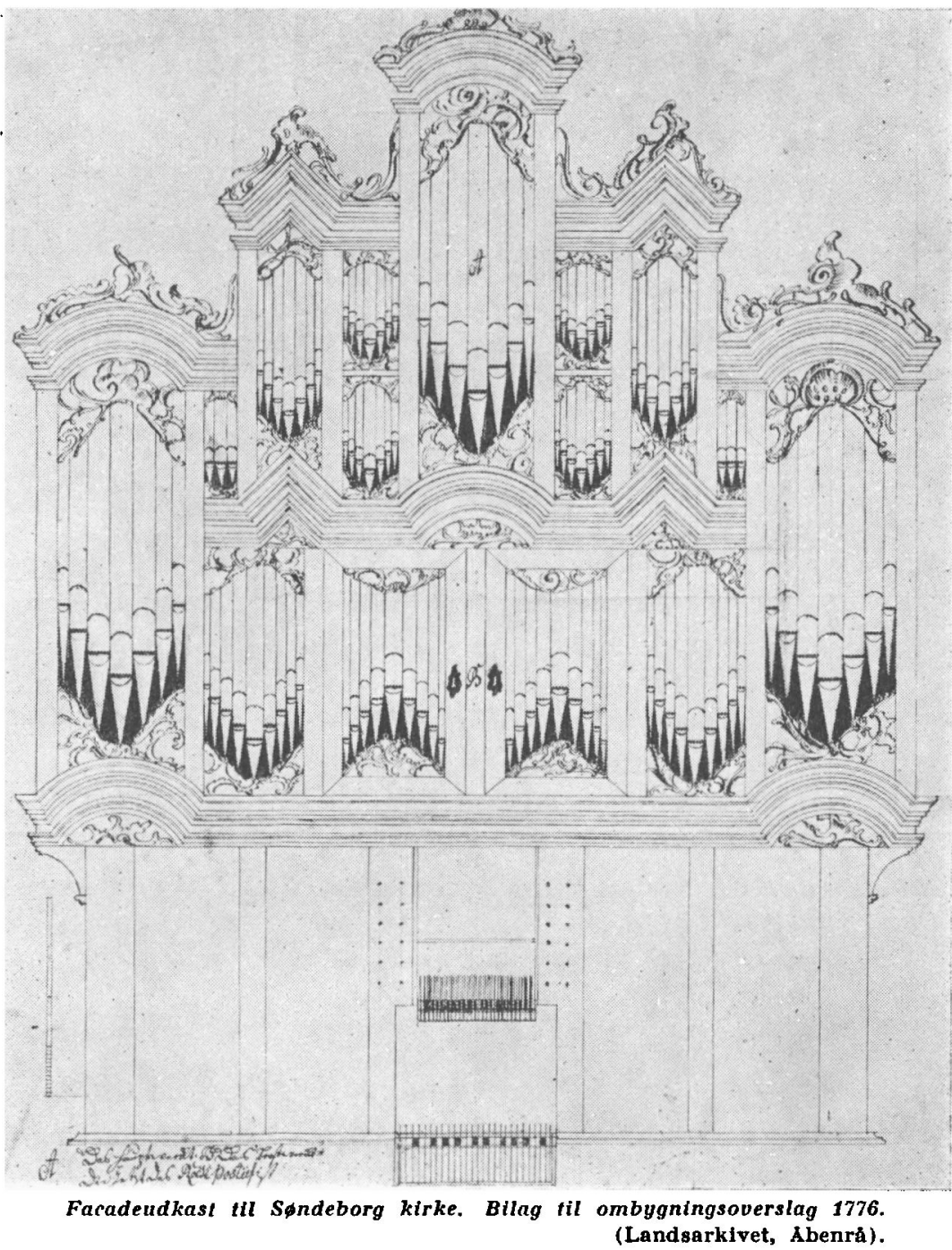

St. Nicolaj kirke, og 1610 istandsatte han orglet i St. Mortens kirke i Randers. Ved denne lejlighed skrev han sig til Sønderborg og kaldte sig "Orgemester her sammesteds ${ }^{6}$. Sandsynligvis har han o. 1604 slået sig ned i Sønderborg som organist og orgelbygger, en kombination, der ingenlunde var ualmindelig i de dage. 
Willers påbegyndte bygningen af Sønderborg-orglet 3. juni 1604, og værket stod færdigt 27. okt. 1606. Desværre kender vi ikke dispositionen for dette instrument, der — så vidt vides var Willers eneste større arbejde på dansk grund. I kirkens arkiv ligger en afskrift af byggeregnskabet ${ }^{\bar{\tau}}$, hvor man år for år kan følge arbejdet, store og små udgifter mellem hinanden, men noget grundlag for en rekonstruktion af dispositionen er der ikke. Efter de samlede udgifter - 1345 mark - at dømme, må der have været tale om et ret stort instrument, og vi ved, at 41 mark blev betalt specielt for et rygpositiv. Man må da formode, at orglet $\mathrm{i}$ alle tilfælde har bestået af tre værker: Hovedværk, rygpositiv, der ikke kunne kobles sammen med hovedværket, og pedal. Pedalet har dog næppe været særligt omfangsrigt; først i 1703, da orglet blev omdisponeret (se s. 236), blev facaden forsynet med særlige bastårne til pedalets piber. I orgelpiberne indgik brugt materiale, således som det fremgår af en udgiftspost til en af kirkeværgerne for en rejse "na dem Reinevelde de Orgelpipen aff tho breken vnd thom Kihle gelevert " (til Reinfelt for at bryde orgelpiberne ned og levere dem til Kiel); fra Kiel er de så bragt til Sønderborg, hvor de formentlig er blevet smeltet om for sammen med nyt metal at genopstå som piber i Willers' orgel.

Endnu et orgel er der gode oplysninger on fra 17. århundrede: Det, der 1636 blev påbegyndt til Ullerup kirke ${ }^{8}$ af en desværre ikke navngivet orgelbygger. Som i Broager kendes dispositionen først fra 1668 , hvor kirkens inventarium ${ }^{\circ}$ meddeler, at orglet havde to manualer og pedal med ialt 14 stemmer: Principal, oktav, mixtur, gedakt, fløjte og trompet i hovedværket; fire ikke nærmere angivne stemmer $\mathrm{i}$ »Positiv « og følgende fire pedalstemmer: Cornetbas, trompetbas, fløjtebas og gedakt. Et ganske anseeligt instrument til en landsbykirke. Det bærende er hovedværket med principalkoret og trompeten, og med de to blidere stemmer gedakt og fløjte, vel henholdsvis 8 og 4 fod. En solostemme mangler i dette værk, men har nok været at finde i positivet. I alle tilfælde må pedalets kornet - et terzregister - betragtes som en udpræget cantus firmus-stemme.

Fra endnu fem kirker har vi oplysninger om orgler på dette tidspunkt. 1645 betales løn til den, der stemmer orglet i Ulkebøl kirke, ${ }^{10}$ og i 1657 løn til den, der træder bælgene, altså et ikke 
helt lille instrument. 1663 forærer hertug Hans et positiv til Nordborg kirke ${ }^{11}$. I Lysabild kirkes regnskabsbog ${ }^{12}$ optræder i regnskabsåret 1693-94 en udgift til en reparation af orgelhuset. I Egen kirke $^{13}$ betales i 1692 for et orgelpulpitur, og året efter får en orgelbygger 6 mark "dae Er das Orgel wieder zu Recht gemacht " (fordi han havde istandsat orglet). Endelig moder vi en orgelreparation i Sottrup ${ }^{14}$ i 1704. Alle disse oplysninger vidner om orgler, der i alle tilfælde kan føres et stykke tilbage i 1600-årene.

Af Sønderborg amts ialt 18 landsbykirker har således syv haft orgler før år 1700; muligvis har der varet flere, men arkivalierne giver kun underretning om disse syv. $\mathrm{Nu}$ er arkivmaterialet til belysning af de sønderjyske kirker langt rigere end for størstedelen af det øvrige Danmarks vedkommende, men selv når det gælder Sønderborg amts kirker er der dog huller; således er materialet vedr. de to sundevedske kirker Dybbøl og Nybøl ret tyndt. Vi kan således »kun* registrere syv orgler; men dette tal dækker dog nær halvdelen af amtets landsbykirker $i$ et århundrede, hvor vi fra det ovrige Danmark kun kender orgler i købstadskirkerne og de største landsbykirker.

Hidtil har arkivalierne kun givet os eet orgelbyggernavn: Joachim Willers; men fra skiftet mellem 17. og 18. århundrede er flere navne bevaret, dog kun i forbindelse med reparationer. Således istandsatte den hamborgske orgelbygger Johan Heinrich Wernitzky i 1685 Bronger kirkes orgel ${ }^{15}$. Han er dog ikke blevet tilkaldt fra Hamburg specielt til denne i sig selv ubetydelige opgave; han virkede i 1684 i Tønder og 1686 i Flensborgs Vor Frue kirke, og Broager har kunnet drage fordel af sin gode beliggenhed.

Den senere domorganist i Viborg Elias Wernitz ${ }^{16}$ reparerede i 1689 Ulkebøl kirkes orgel, og i 1708 istandsætter han i Egen kirke. På dette tidspunkt skrev han sig til Frøskøbing. Han forenede - som så mange på dette tidspunkt - en organists og en orgelbyggers gerning. Det samme kan være tilfældet med den ellers ukendte Peter Lorentzen, der 1706 reparerede orglet i Egen kirke. Fra begyndelsen af 18. århundrede kendes også Flensborgorgelbyggeren Hans Vent, der i 1715 blev tilkaldt til en reparation af Ảbenrå kirkes orgel; han foretog istandsættelser i Egen 1715, Sottrup 1728 og Ulkebol 1731" 
Om den klassiske epoke $\mathrm{i}$ dansk orgelbygning - det 18. århundrede - har vi gode oplysninger i de sønderborgske arkivalier, dels om reparationer, dels om nybygninger og omdisponeringer. Blandt de ældste af de betydeligere orgelbyggere møder vi Heinrich Wiese, der i 1703 fik til opgave at udvide og ombygge Willers' orgel i Sønderborg. Wiese kom fra Tyskland, og da han i 1696 reparerede orglet i Ullerup kirke ${ }^{18}$, opgav han sit hjemsted til Kiel, mens han i 1703 kom fra Rendsborg.

Kontrakten ${ }^{18}$ mellem Wiese og Sønderborg kirke er bevaret, og af den fremgår ændringerne: I hovedværket skulle tilføjes en trompet 8 fod, og mixtur III skulle udvides til mixtur IV; rygpositivet skulle have to ny registre: Sesquialtera II og Mixtur III, og gedakt 4 fod skulle ændres til en gedakt 8 fod. Samtidig skulle dette værk have en helt ny vindlade. I Pedalet fandt en gennemgribende ændring sted, to nye vindlader blev bygget og tre stemmer tilføjet: Oktav 4 fod, mixtur IV og trompet 16 fod. Denne forøgelse bevirkede, at façaden fik tilbygget to bastårne. Og som et ekstra raffinement fik instrumentet et klokkespil med otte klokker.

Efter denne ombygning var Sønderborg-orglet bragt i kontakt med det allernyeste fra den nordtyske orgelbygger-skole; det, som den store mester Arp Schnitger ${ }^{20}$ indledte med Jacobi-orglet $\mathbf{i}$ Hamburg i 1686. I Sønderborg blev hovedværkets tyngde kraftigt understreget med udvidelsen af mixturen og trompeten. Rygpositivet fik mere karakter af selvstændigt værk og fik den stemme, der næsten er uundværlig i et højbarokt instrument: Sesquialtera II, et flerkoret terzregister beregnet til solospil. Pedalets betydning blev understreget stærkt, klangligt ved de tre nye stemmer, der krævede to nye vindlader, og synligt ved tilbygning af façadens pedaltårne.

$\mathrm{Nu}$ er der ikke tale om en nybygning, kun om en omdisponering, og Wiese har vel heller ikke nået de schnitgerske højder; men de tanker, der lå bag dispositionsændringen i Sønderborg i 1703, var de samme, som besjalede Schnitger og hans elever i skabelsen af det højbarokke orgel. Denne retning inden for orgelbygningen fik først rigtigt sit gennembrud i det øvrige Danmark over 30 år senere med den store orgelbygger Daniel Lambert Kastens ${ }^{21}$. 
Arp Schnitger døde i 1719, og hans elev Kastens blev i 1721 hans efterfølger som priviligeret orgelbygger ${ }^{22}$ for Slesvig og Holsten samt i grevskaberne Oldenburg og Delmenhorst. Kastens indrettede sit værksted i Itzehoe, og første gang vi møder ham som selvstændig orgelbygger på dansk grund er i 1721. I dette år indgav han et forslag til en ombygning af orglet i Ullerup ${ }^{23}$. Vi ved ikke, om disse planer blev realiseret - regnskaberne tier herom - men det er forsåvidt uden betydning i denne sammenhæng.

Ullerup-orglet stammer fra 1636 , og dets disposition kendes fra 1668 (se s. 234) : i 1696 var det blevet istandsat af orgelbygger Wiese $^{24}$. Kastens optegnede i 1721 dispositionen, som den var, og som han anskede den, og da orglet mellem 1696 og 1721 ikke har været underkastet større reparationer, kan Kastens optegnelse fra 1721 med visse forbehold tages som udtryk for dispositionen for det af Wiese istandsatte orgel. I det følgende opstilles dispositionerne 1668, 1696 (1721) og Kastens forslag:

\begin{tabular}{|c|c|c|}
\hline $\begin{array}{l}1668 \\
\text { Hovedvaerk }\end{array}$ & $\begin{array}{l}1696 \\
\text { Hovedvaerk }\end{array}$ & $\begin{array}{l}\text { Kastens } \\
\text { Hovedværk }\end{array}$ \\
\hline $\begin{array}{l}\text { principal } \\
\text { oktav } \\
\text { mixtur } \\
\text { trompet } \\
\text { gedakt } \\
\text { fløjte }\end{array}$ & $\begin{array}{l}\text { principal } 8^{\prime} \\
\text { oktav 2' } \\
\text { mixtur II } \\
\text { trompet } 8^{\prime} \\
\text { gedakt } 8^{\prime} \\
\text { quint } 22 / 3^{\prime}\end{array}$ & $\begin{array}{l}\text { principal 8' } \\
\text { okiav 4' } \\
\text { oktav 2' } \\
\text { mixtur IV } \\
\text { trompet 8' } \\
\text { gedakt 8' }\end{array}$ \\
\hline Positiv & Brystvaerk & Brygtværk \\
\hline $\begin{array}{l}\text { fire } \\
\text { stemmer } \\
\text { næevnes }\end{array}$ & $\begin{array}{l}\text { gedakt } 8^{\prime} \\
\text { gedakt } 4 ' \\
\text { quint } 11 / 3^{\prime} \\
\text { quint } 1 / 3^{\prime}\end{array}$ & $\begin{array}{l}\text { gedakt } 8 \\
\text { gedakt } 4 \\
\text { quint } 11 / 3 \\
\text { Sesquialtera } \text { II }\end{array}$ \\
\hline $\begin{array}{l}\text { Pedal } \\
\text { kornet } \\
\text { trompet } \\
\text { fløjte } \\
\text { gedakt }\end{array}$ & $\begin{array}{l}\text { Pedal } \\
\text { kornet II } \\
\text { trompet } 8^{\prime} \\
\text { waldfl } \varnothing \text { jte } 2 \text { ' } \\
\text { gedakt } 8^{\prime}\end{array}$ & $\begin{array}{l}\text { Pedal } \\
\text { dulcian } 16 \\
\text { trompet } 8^{\prime} \\
\text { oktav 4' } \\
\text { gedakt } 8^{\prime}\end{array}$ \\
\hline
\end{tabular}

Wieses ændringer har ikke været store, da hele reparationen kostede 97 mark. De har vel indskrænket sig til quinten i hovedværket og måske den ejendommelige sammenstilling af de to 
quint-registre i brystværket. Kastens ændringsforslag er anderledes radikalt, og selv om planerne muligvis ikke blev fort ud i livet, så giver de et indtryk af denne betydelige orgelbygger på det tidligste tidspunkt $i$ hans karriere.

Ved at udskifte fem af orglets 14 stemmer ville Kastens skabe grundlag for det højbarokke klangbillede. I hovedværket skulle quinten erstattes af oktav 4' og mixtur udvides til mixtur IV. hvorved principalkoret blev ført helt igennem; trompet 8' og gedakt 8' kunne blive stående. Wiese havde i hovedværket knyttet en quint til gedakten; Kastens fjernede quinten og lod gedakten stå alene i fuld overensstemmelse med Schnitgers principper, der foreskrev et enkeltstående, vidt-mensureret register til at understrege grundtonen ${ }^{23}$.

I brystværket ville Kastens fjerne den mindste quint og sætte højbarokkens yndlingsstemme, terzregistret sesquialtera $\mathbf{i}$ stedet. Den skulle som solostemme erstatte pedalets kornet II. Herved blev der i pedalet plads til en dulcian 16', en stemme, der skulle understrege pedalets karakter af selvstændigt værk. Ved så enkle midler ville Kastens omdanne det forældede instrument til et orgel helt $\mathbf{i}$ højbarokkens ånd: De tre værkers karakter blev understreget, hovedværket fik principalkoret, brystværket de blidere slemmer og soloregistrene, og pedalet fik ved dulcian stemmen 16-fods klang. Dette viser Kastens med Schnitgers læresætninger i frisk erindring og gennemsyret af de principper, der skulle blive toneangivende for hans betydningsfulde virke i Danmark.

Da Kastens i 1720erne tog til Kabenhavn, hvor store opgaver ventede ham især efter byens brand $\mathbf{i} 1728$, førtes hans orgelbyggervirksomhed i Itzehoe videre af hans svoger Johann Dietrich Busch $^{26}$. Denne orgelbygger fik naturligt et virkefelt i Sønderjylland, og også i Sønderborg amt træffes han ofte. Han foretog fire større reparationer, Sottrup $(1740)^{27}$, Ullerup $(1740)^{28}$, Ulkebol $(1748 \text { og 54) })^{20}$ og Egen $(1768)^{\text {so }}$. Vi har efterretning om fire nye instrumenter fra hans hånd: Broager fra $1740^{31}$, Sottrup $1761^{32}$, Ullerup $1766^{\text {ss }}$ og Ulkebol $1768^{34}$. Af dispositionerne kendes kun to, den første og den sidste. 


$\begin{array}{ll}\begin{array}{l}\text { Broager 1740 } \\ \text { Manual }\end{array} & \begin{array}{l}\text { Ulkeb } \phi^{\prime} 1768 \\ \text { Øverste manual }\end{array} \\ \text { principal 8' } & \text { principal 8' } \\ \text { oktav 4' } & \text { oktav 4' } \\ \text { oktav 2' } & \text { oktav 2' } \\ \text { mixtur IV } & \text { mixtur IV } \\ \text { trompet 8' } & \text { quint 2 2/3 } \\ \text { quint 2 2/3 } & \\ \text { siffløjte 1 1/3 } & \\ & \\ \text { Brystvæerk } & \\ \text { gedakt 8' } & \\ \text { fløjtegedakt 4' } & \text { Underste manual } \\ \text { oktav 2' } & \text { quintadena 8' } \\ \text { sesquialtera II } & \text { fløjte 4' } \\ \text { oktav 2' } \\ \text { cimbelstern og tremu- } & \text { sesquialtera II } \\ \text { scharff III } \\ \text { lant. Anhangspedal } & \text { anhangspedal: Quinta- } \\ \text { uden særlige registre. } & \text { dena 16' i diskant, i } \\ & \text { bas basun eller } \\ \text { trompet 16' }\end{array}$

To orgler i tidens traditionelle stil. Hovedværket rummer i begge tilfælde principalkoret, mens de blidere registre og solostemmen sesquialtera er sat $i$ andet manual. Anbringelsen af trompet 8' i Ulkebol-orglets underste manual kan synes noget inkonsekvent, den burde - som i Broager - være anbragt i hovedværket sammen med principalkoret, men pladsforholdene kan have været afgørende for placeringen. Begge orgler har anhangspedal, men kun Ulkebøls et særligt pedalregister, en 16-fods stemme, delt $\mathbf{i}$ den blide quintadena $\mathbf{i}$ diskanten og den kraftigere lungestemme basun eller trompet $\mathbf{i}$ bassen.

Johann Dietrich Buschs søn Johan Daniel Busch ${ }^{35}$, der 1753 havde fảet koncession som orgelbygger, leverede i 1773 et nyt orgel til Augustenbory slotskape ${ }^{36}$. Det var et instrument på 22 stemmer fordelt på hovedværk, overværk og pedal. Hovedværk og pedal havde hver to vindlader, mens overværket havde een. Dispositionen, som den fremgår af en optegnelse fra 1777: 


\begin{tabular}{|c|c|c|}
\hline $\begin{array}{l}\text { Hovedværk } \\
\text { principal } 8^{\prime} \\
\text { oktav 4' } \\
\text { oktav 2' } \\
\text { mixtur IV } \\
\text { trompet } 8^{\prime} \\
\text { bordun 16' } \\
\text { viola di gamba } 8^{\prime} \\
\text { quint 2 2/3' } \\
\text { cimbel III } \\
\text { gedakt 8' }\end{array}$ & $\begin{array}{l}\text { Overværk } \\
\text { quintadena } 8^{\prime} \\
\text { rørfløjte 8' } \\
\text { principal 4' } \\
\text { hohlfløjte 4' } \\
\text { waldfløjte 2' } \\
\text { vox humana 8' } \\
\text { kornet 4' } \\
\text { traversfløjte 8' }\end{array}$ & $\begin{array}{l}\text { Pedal } \\
\text { subbas } 16^{\prime} \\
\text { basun } 16^{\prime} \\
\text { principal } 8^{\prime} \\
\text { trompet } 4^{\prime}\end{array}$ \\
\hline
\end{tabular}

Der er en afgiort forskel på faders og søns værker; mens Johann Dietrich Busch holdt sig til de traditionelle veje, søgte sønnen at skabe muligheder for mere nuancerede klangbilleder, hvad der faldt ham så meget lettere, da orglet havde 22 stemmer. Johan Daniel Busch søgte nye veje, og hans Augustenborg-orgel fra 1773 falder godt i tråd med de instrumenter, der byggedes i Danmark, i overgangstiden mellem barokken og det romantiske orgels gennembrud i 19. århundrede.

I midten af århundredet blev Sønderborg kirkes orgel igen istandsat. 1757 sluttede kirken kontrakt med Glückstadt-orgelbyggeren Matthias Schreiber ${ }^{37}$, der dels skulle foretage en gennemgribende istandsættelse af mekanikken og piberne, som var angrebet af tinpest, og dels modernisere orglet, idet det skulle stemmes om. Det havde hidtil været stemt i den såkaldte korte oktav, således at visse toner manglede, f. eks. i dybe oktav Cis, Dis, Fis og Gis. En sådan mangel kunne man til nød affinde sig med på de små orgler, men på et instrument af størrelse som det i Sønderborg var det uholdbart, især når man tænker på, hvad datidens "moderne" musik, f. eks. Johan Sebastian Bachs, stillede af krav til instrumenterne.

Slutningen af 18. ârhundrede domineredes i Sønderborg amt af orgelbyggeren Jürgen Heinrichsen Angel fra Flensborg. Denne orgelbygger, der ellers er ukendt $i$ Danmark, byggede sit første instrument i Egen kirke ${ }^{38}$ 1773-75. Det bestod af tre værker med følgende disposition (efter kontrakten): 


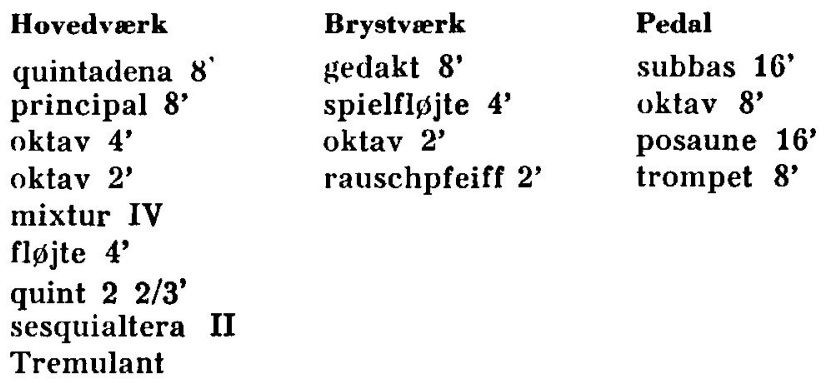

Endvidere blev orglet forsynet med en forgyldt cimbelstern" Dispositionen til dette orgel er ikke udarbejdet af Angel selv, men derimod af organist Fischer fra Nordborg, som ifølge kirkens regnskaber ${ }^{40}$ fik 2 rigsdaler for dette arbejde. Angel var begynder på dette tidspunkt, således som det fremgâr af Fischers synsforretning ${ }^{41}$ fra 1775 , hvor det til sidst hedder: $»$ Da es das erste von ihm alhier neugesetzte Werck ist, für ein MeisterStücke völlig passiren könne" (da dette er hans første helt nybyggede værk, kan det helt igennem passere som et mesterstykke).

Allerede året efter sin orgelbygger "debut " optrådte Angel på egen hånd. I 1776 fik han til opgave at forestá en hovedreparation af Sønderborg kirkes orgel ${ }^{42}$. For 600 mark skulle han gennemreparere instrumentet (men næppe ændre ved dispositionen), og levere et nyt orgelhus af fyrretræ. Ved sagens akter ligger en sirligt udført tegning til en meget pompøs façade, der vidner om en ikke ringe konservatisme hos sin skaber, forudsat tegningen virkelig stammer fra 1770'erne (se s. 233).

I de følgende år fik Angel fuldt op at gøre i amtets kirker. Fra 1786 og 1792 er overleveret to næsten enslydende dispositioner til orgler i Hagenbjerg $g^{43}$ og Notmark $k^{44}$ kirker: Principal 8', oktav 4', oktav 2', mixtur IV, trompet 8', gedakt 8', fløjte 4', sivfløjte $1 \frac{1}{3}$, quint $2^{2 / 3^{\prime}}$, sesquialtera II, tremulant, cimbelstern og i Notmark dulcian 16 ' i bassen.

Denne opbygning af en disposition er ganske traditionel og adskiller sig ikke fra, hvad der var gængs i århundredets midte (sml. dispositionerne s. 239).

Noget anderledes stiller det sig med det orgel, Angel i 1787 sluttede kontrakt om at bygge til Ulkebol kirke ${ }^{45}$, til afløsning af 
Buschs knapt 20 âr gamle instrument. Det skulle have tre værker med følgende disposition:

Hovedvark
principal $8^{\prime}$
oktav 4'
oktav 2'
mixtur IV
trompet 8'
bordun 16'
viola di gamba 8'
quint 2 2/3'
cimbel III
gedakt 8'
cimbelstern med otte
klokker.

\begin{tabular}{|c|c|}
\hline $\begin{array}{l}\text { Overvwrk } \\
\text { gedakt 8' } \\
\text { rørfløjte 8' } \\
\text { gemshorn 8' } \\
\text { principal 4' } \\
\text { oktav 2' } \\
\text { scharff III } \\
\text { vox humana 8' } \\
\text { krumhorn 8' } \\
\text { trayersfløite 8' }\end{array}$ & $\begin{array}{l}\text { Pedal } \\
\text { subbas 16' } \\
\text { posaune 16, } \\
\text { dulcian 16', } \\
\text { principal } 8^{\prime} \\
\text { oktav 4' } \\
\text { trompet 4' }\end{array}$ \\
\hline
\end{tabular}

Mens Angels tidligere dispositioner næsten var tro kopier af Johann Dietrich Buschs, sả viser opbygningen af Ulkebøl-orglet nye træk, og dog - lader man blikket glide hen pà Johan Daniel Buschs Augustenborg-disposition fra 1773 (se s. 240), falmer Angels originalitet. Hovedværkerne i Augustenborg og Ulkebøl er fuldstændig identiske, og de to instrumenter har $\mathrm{i}$ andet manual ikke mindre end fire stemmer fælles, deriblandt den på dette tidspunkt forsvindende traversfløjte. Også pedalværkerne har fire registre fælles, og her hæfter man sig især ved anvendelsen af en trompet i 4-fods lejet, et ikke ganske ordinært fænomen. $V i$ ved endvidere, at registrene skulle fordeles pâ vindladerne ganske som i Augustenborg.

Denne lighed er ikke tilfældig. Netop i disse ar blev hele Ulkebøl kirkes indre omdannet med Augustenborg slotskapel som forbillede; og for orglets vedkommende kunne man ikke nøjes med at efterligne Augustenborgs façade og ligesom dér at anbringe den over alteret, men også selve værket måtte kopieres. Om det så var organisten, fulgte han med fra Augustenborg; i 1790 synede Christian Rudolph Ebeling ${ }^{48}$ som Ulkebøl sogns nye organist sammen med sin efterfolger i Augustenborg, slotsorganist Hansen, Angels nye orgel ${ }^{47}$. Her klages bl. a. over, at Angel i overværket har sat en gemsquint $2^{2} / \mathbf{s}^{\prime}$ istedet for det $\mathbf{i}$ kontrakten anførte gemshorn 8'. Angel anfører til sit forsvar, at værket havde for mange 8-fods stemmer - hvad man kun kan give ham ret $\mathbf{i}$-, 
livorfor han foretrak en quint. De to organister giver ham forsåvidt ret, men mener, at Angel sâ passende kumne have erstattet gemshornet med endnu et 4-fods register. Endvidere havde Angel istedet for krumhorn 8' i overværket sat en dulcian 8'.

Til sidst $i$ synsforretningen klager de to organister over, at Angel har lavet mixturenes piber for små, man onsker den af samme storrelse som i Augustenborg. Dette lover Angel at ændre, men anfører dog, at der ikke i kontrakten var bestemt noget om mixturepibernes storrelse, sà han havde udfort dem, som han plejede; det vil vel igen sige, sådan som Johann Dietrich Busch plejede.

Nu skal man selvfølgelig ikke fratage Angel enhver form for originalitet, men han ligger familien Buschs tradilioner páfaldende nær. $\mathrm{Og}$ hertil kommer, at man ingen udvikling $\mathrm{kan}$ spore hos denne orgelbygger. I $\mathbf{1 7 8 6}$ byggede han et orgel til Hagenbjerg kirke, der helt var $i$ fader Buschs and, d. v. s. højbarokkens. Året efter bekendte han sig i Ulkebol-orglet til overgangsstilen, under påvirkning af Busch den Yngres Augustenborg-orgel, og vel under pres fra kirkens patron og organist Ebeling, for i Notmark-orglet fra 1792 at falde tilbage på traditionerne fra fader Buschs tid.

Den sidste del af 18. og den forste af 19. árhundrede er for Damnarks orgelbygning en overgangstid, man kan mâske tale om en stilstand. Det varede adskillige år før de mange muligheder, der lå i højbarokkens instrumentbygning, var udtømt. Der blev arbejdet videre, men nyhederne var kun få, simpelthen fordi den tradition, som - med rette eller urette - bærer Schnitgers navn var så rig og sà nuanceret. Efter pionertiden kom en epoke med flittigt arbejde; i dag stâr der măske ikke så megen glans om denne tids orgelbyggere, men man må ikke glemme, at det var disse mestre, der virkede, da så mange danske kirker fik orgler. Hvis man $i$ orgelhistorien kun ser efter nyskabelser og store, epokegorende instrumenter, kan man betegne dette tidsrum som en dvale; men set under en bredere synsvinkel må den karakteriseres som en arbejdstid, hvor de mange muligheder blev gennemprøvet.

Hen mod midten af 19 . àrh. begyndte romantikken for alvor at gøre sig gældende inden for orgelbygningen. Man forlod den strenge opdeling i værker, og lod det da fuldtudviklede symfoni- 
orkester være klangidealet. Denne bevægelse kulminerede i Danmark med Daniel Köhne; han var elev af den store franske mester Cavaillé-Coll, skaberen af det instrument, Cesar Francks værker er skrevet for. I 1870 byggede Köhne sit første store orgel i Holmens kirke i København ${ }^{47 *}$, og andre fulgte efter.

Reaktionen mod romantikken satte ind efter forste verdenskrig; Albert Schweitzer indvarslede orgelbevægelsen, det klassiske orgel blev genopdaget og det romantiske blev fordømt. Denne bevægelse var orgelbygningens svar på de strømninger, der havde rørt sig i tidens musikliv, her hjemme først og fremmest med Carl Nielsen og Thomas Laub. Både inden for kirkemusikken og orgelbygningen skabte bevægelsen meget godt og sundt, men det gik ikke for sig uden of re, og et af ofrene blev de romantiske orgler. For mens den romantiske musik blot kunne gemmes, så blev der ryddet godt ud i instrumenterne.

Af romantikkens orgler er snart ikke mange tilbage. Endnu står Daniel Köhnes store instrument $\mathrm{i}$ Viborg domkirke; måtte det blive bevaret som et monument over en epoke, der målt med historiens målestok er ligeså værdifuld som barokken. For set på langt sigt er orgelbevægelsen en moderetning som så mange andre, og dens idealer er ud fra denne synsvinkel ikke bedre og mere rigtige end f. eks. romantikkens.

Det har ikke været muligt at give en vurdering af 19 . århundredes orgelbygning i Sønderborg amt, da en samlet undersøgelse for Danmark mangler. Her må jeg nøjes med at fremlægge det vigtigste sønderborgske materiale, og så håbe, at det engang vil kunne indgå $i$ en samlet undersøgelse af 19. århundredes danske orgelbygning.

Tidligst $i$ århundredet mødes Jørgen Marcussen ${ }^{48}$, grundlæggeren af det endnu eksisterende orgelbyggerfirma i Ảbenrå. Efter at have lært sit håndværk hos Oppenhagen i Rudkøbing vendte han tilbage til sin fødeegn Sundeved, hvor han i 1811 fik koncession som orgelbygger.

Fra samme år er bevaret et brev fra kirkeværgen i Ullerup til kirkevisitatoriet ${ }^{49}$, hvori det hedder, at orgelbygger Angel ${ }^{40 *}$ junior fra Flensborg ikke kommer til Ullerup $i$ år for at føre tilsyn med orglet, derfor foreslås, at parcellist og snedker Jørgen Marcussen »auf Kundsgaardfeld i dette sogn, som har fảet koncession til at 
drive orgelbyggerprofession, må overtage tilsynet med orglet.

1811 foretog Jørgen Marcussen mindre reparationer på orglerne i $E_{g e n^{50}}$ og Hagenbjerg ${ }^{51}$ kirker, og efterhânden overtog han tilsynet med de fleste af amtets kirkeorgler. Marcussen blev det dominerende orgelbyggernavn i landsdelen, først under Jørgen Marcussens eget navn, senere som Marcussen \& Reuter, og endelig under det navn, firmaet bærer i dag, Marcussen \& Søn. I det følgende vil to af firmaets nybygninger, som de bevarede kirkearkivalier giver fyldige oplysninger om, blive refereret.

I 1841 indgav Marcussen \& Reuter et overslag vedrørende et nyt orgel til Sottrup kirkes"; overslaget blev i 1843 ophøjet til kontrakt.

\begin{tabular}{|c|c|c|}
\hline $\begin{array}{l}\text { Hovedvark } \\
\text { principal } 8^{\prime} \\
\text { oktav 4' } \\
\text { superoktav 2' } \\
\text { bordun 16' } \\
\text { rørfløjte 8' } \\
\text { quint } 22 / 3 \text { ' } \\
\text { tertz } 13 / 5^{\prime} \\
\text { trompet } 8^{\prime}\end{array}$ & $\begin{array}{l}\text { Overvierk } \\
\text { gedakt 8' } \\
\text { viola di gamba 8' } \\
\text { fugara 4' } \\
\text { flajte 4' (dækket) }\end{array}$ & $\begin{array}{l}\text { Pedal } \\
\text { subbas } 16^{\prime} \\
\text { violoncello } 8 \\
\text { posaune } 16^{\prime}\end{array}$ \\
\hline
\end{tabular}

Af disse skulle principal 8' og bordun 16' i hovedværket have snæver mensur. En cimbelstern med akkorden g-h-d-g blev tilføjet efter menighedens ønske, men meget mod de to orgelbyggeres vilje. Pladsforholdene i overværket bevirkede, at den store oktav i gedakt 8' blev lånt i hovedværkets rørfløjte, og de piber, der skulle danne tonerne $\mathrm{C}-\mathrm{H}$ i viola di gamba blev lånt $\mathrm{i}$ hovedværkets principal, der som for nævnt havde snæver mensur, hvorved den klangligt ville stå strygestemmen viola di gamba nær. Karakteristisk er det klangligt brede hovedværk og det blide overværk, helt i overensstemmelse med "moden" omkring midten af forrige århundrede.

I 1872 bevilgedes 900 daler til et nyt orgel i $E$ gen kirke $^{53}$, og samme år indgav Marcussen \& Son et overslag ${ }^{54}$ på et orgel med et manual og anhangspedal med følgende otte stemmer: Principal 8', oktav 4', oktav 2', bordun 16', viola di gamba 8', gedakt 8' og quint $2^{2} / 3^{\prime}$. I 1892 fik kirken råd til at udvide orglet, og også dette blev lagt i hænderne på Marcussen \& Søn ${ }^{\mathrm{s}}$. Instrumentet fik endnu et manual (og tilmed $i$ svelle) med følgende tre registre: 
Gamba 8', flauto amabile 8' og rørfløjte 4'. Gamben skulle overflyttes fra det allerede eksisterende manual, der istedet fik et overblæsende register: äben fløjte 8'.

Også ombygninger gav Marcussen \& Søn sig af med, săledes en i 1854, hvor firmaet indleverede et overslag til en ombygning af orglet i Hagenbjerg kirke ${ }^{55 *}$; orglet her var bygget 1786 af Angel (disposition se s. 241), og det blev af Marcussen i 1854 betegnet som vet fra ny mådelig forfærdiget, nu forfaldent og tildels mangelfuldt instrument «. Orglet skulle nu moderniseres, og Marcussen \& Søn foreslog, at man ændrede Sesquialtera II $\left(\mathrm{C}=\mathbf{2}^{2} / \mathbf{3}^{\prime}\right.$ og $\left.13 / 5^{\prime}\right)$, mixtur IV skulle udvides til mixtur $V$, og den forældede siffløjte $13 / 5$ ' skulle erstattes af fugara 4'.

Endnu en orgelbygger fra 19. århundrede fortjener at blive nævnt: Demant fra Dalum ved Odense. Han har bygget orgler bl. a. til Budolfi kirke i Aalborg, til kirkerne i Faaborg, Kerteminde og Dalum, og til St. Hans, Gråbrødre og Vor Frue kirker i Odense. Han mødes to steder i Sønderborg amt. Senest 1856 i Notmark ${ }^{56}$, men desværre er alt, hvad vi ved om Demants orgel her, at der blev betalt 13 rigsdaler for at få det synet.

1852 indgav Demant overslag ${ }^{57}$ over udgifterne til et nyt orgel til Sonderborg bykirke. Overslaget blev 1853 ophøjet til kontrakt. Ifølge denne skulle orglet have hovedværk, overværk og pedal med 16 stemmer $\mathrm{i}$ følgende disposition:

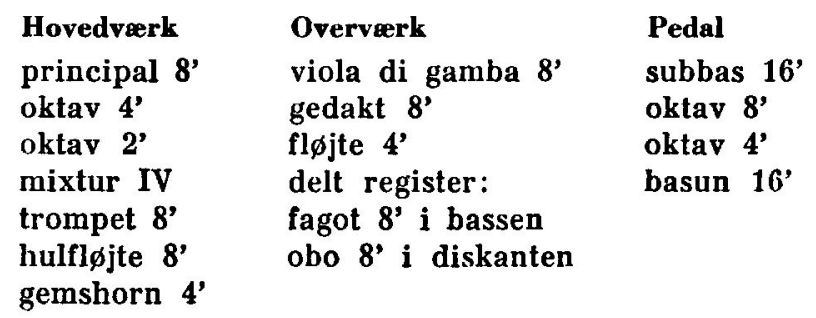

Meget $i$ denne disposition er klassisk, sâledes hovedværkets opbygning med fuldt principalkor og trompet; at mensuren og dermed klangfarven har været en anden, end den vi kender fra 18. århundrede, er så en anden sag. Vel det mest karakteristiske $i$ dette orgel er det delte register fagot 8 ' - obo 8' i overværket; denne stemme skulle gore det muligt for organisten at udføre det i den romantiske tidsalder så yndede følsomme solospil med de blideste hovedværks-registre som akkompagnement. 
Med arkivstudier som eneste grundlag har det været muligt at følge orglets udvikling $i$ et enkelt sønderjysk amt. Vi har mødt store og små mestre mellem hinanden, renaissancens Joachim Willers, en Kastens i svøb, den dygtige familie Busch, den hidtil ukendte Jürgen Heinrichsen Angel, og endelig Marcussen og Demant. Og vi har mødt disse orgelbyggere under arbejdet med de små instrumenter, der rundt omkring i sognene har ledsaget menighedens salmesang. Kunstspil i større stil har disse orgler ikke været brugt til; forbavsende er det derfor at se, hvor hurtigt modestrømningerne inden for orgelbygningen kan mærkes selv i de mindste instrumenter. Derfor har også landsbykirkernes orgler deres plads $i$ orgelhistorien, og en af hensigterne med at offentliggøre de sønderborgske kilder har været at vise, hvor rigt el materiale arkiverne gemmer.

\section{NOTER OG HENVISNINGER}

\section{Litteratur:}

Hans Klotz: über die Orgelkunst der Gotik, der Renaissance und des Barocks, 1934.

Hans Klotz: Das Buch von der Orgel, 1955.

Poul-Gerh. Andersen: Orgelbogen, 1956.

Niels Friis: Orgelbygning i Danmark, 1949.

Når intet andet anfọres findes arkivmaterialet i Landsarkivet i Åbenrå.

1. Denne gennemgang er foretaget til brug for det kommende bind af Nationalmuseets værk ,Danmarks Kirker : Sønderborg amt. Her vil orgelfaçadlerne blive behandlet, mens nærværende redegørelse kun omhandler dispositionerne.

2. Sønderborg provstearkiv (f $\phi r$ 1879) : Kirkeregnskabsbog for Broager 1566-1652.

3. Sønderborg provstearkiv ( $f ø r$ 1879) : Kirkeregnskabsbog for Broager 1653-1780. Dispositionen findes $i$ det inventarium fra 1668, der indleder bogen.

4. I de $i$ note 2 og 3 næunte regnskabsb $\varnothing$ ger findes følgende: 1608 rensning ved Joachim Willers, 1625 bælgreparation ved Jürgen organist fra S $\emptyset$ nderborg, 1625 bælgreparation ved Hans Clausen, 1635 reparation for 166 mark og 1662 rensning.

5. Wilhelm Stahl: Lübecks Orgeln, 1939.

6. Niels Friis: Orgelbygning i Danmark s. 31.

7. Sønderborg præstearkiv: Sager til den gamle arkivfortegnelse afd. $6,1563-1831$. Forsk. sager vedr. kirkevæsenet nr. 2, 26 a-b, 36-37.

8. Ullerup præstearkiv: Ca.1. Kirkeregnskabsbog, $1606-50$.

9. Sønderborg provstearkiv (f $\phi r$ 1879): Kirkeregnskabsbog for Ullerup, $1653-1780$

10. LA. Ab. Alsiske kirkeregnskaber: Ulkebøl, 1632-1713 div. år.

11. Revid. regnsk. Kirkeregnskaber: Nyborg provsti. $1662-71$

(i Rigsarkivet).

12. Augustenborg kirkeinspektorat: Lysabild kirkeregnskabsbog. $1691-1741$.

13. Egen præstearkiv: Ca.1. Kirkeregnskabsbog 1667-1742. 
14. Foretaget af Heinrich Wiese. Sønderborg provstearkiv (f $\phi r$ 1879) : Kirkeregnskabsbog for Sottrup, 1635-1780.

15. Sønderborg provstearkiv (f $\varnothing \mathbf{r} 1879$ ): Kirkeregnskabsbog for Broager 1653-1780, Niels Friis: Orgelbygning i Danmark, s. 108 ff.

16. Ulkebøl præstearkiv: Kirkeregnskabsbog, 1589-1691/92, Egen præstearkiv: Ca.1. Kirkeregnskabsbog, 1667-1842, Niels Friis: Orgelbygning i Danmark.

17. Egen præstearkiv: Ca.1. Kirkeregnskabsbog, 1667-1742, Sønderborg provstearkiv ( $\varnothing \mathrm{r}$ 1879): Kirkeregnskabsbog for Sottrup, 1635-1780, Ulkeb $ø l$ præstearkiv: Kirkeregnskabsbog 1691/921740/41, Niels Friis: Orgelbygning i Danmark.

18. Sønderhorg provstearkiv (før 1879): Kirkeregnskabsbog for Ullerup, $1653-1780$.

19. Kontrakten findes $i$ den $i$ note 7 næunte pakke.

20. En vurdering af Arp Schnitger findes i Poul-Gerh. Andersens og Hans Klotz' bøger. Schnitgers betydning i Danmark se Niels Friis: Anf. sted s. $113 \mathrm{ff}$.

21. Niels Friis: anf. sted s. 125 ff.

22. En kopi af privilegiebrevet findes $i$ den $i$ note 7 nævnte pakke.

23. Ullerup præstearkiv: $H$. 3. Kirken og dens inventar, $1696-1903$.

24. Arkivalierne vedr. denne sag findes $i$ den i note 23 nævnte pakke, sml. note 18.

25. Sml. gedakt 8' i rygpositivet i Schnitgerorglet i Hamburgs Jacobikirke. Dispositionen gengivet i Poul-Gerh. Andersen: Orgelbogen, s. 221 .

26. Niels Friis: Orgelbygning i Danmark s. 126, 131, 133, 152.

27. S $\varnothing$ nderborg provstearkiv (f $\phi \mathbf{r}$ 1879): Kirkeregnskabsbog for Sottrup, 1653-1780.

28. Sønderborg provstearkiv (før 1879): Kirkeregnskabsbog for Ullerup, $1653-1780$.

29. Ulkeb $\varnothing 1$ præstearkiv: Kirkeregnskabsbog, 1691/92-1775/76.

30. Egen præstearkiv: Ca.l. Kirkeregnskabsbog, 1667--1742.

31. Sønderborg provstearkiv (f $\not r$ 1879): Kirkeregnskabsbog for Broager, $1653-1780$. Dispositionen findes i Rigsarkivet i København i pakken: Glücksborg E. Kirke og Skole 81. Almindelige sager vedr. kirkelige forhold $1637-1779$.

32. Den i note 27 nævnte kilde.

33. Den i note 28 nævnte kilde.

34. De augustenborgske godser, aflevering fra Kiel: C. IV. nr. 126, Ulkeböl, Kirchensachen u. Kirchhof, 1763-1851.

35. Niels Friis: anf. sted, s. 152.

36 Christiansfeld brødremenigheds arkiv $\mathrm{V} \cdot \mathrm{A} \cdot \mathrm{R} \cdot \mathbf{1 3}$

37. S $\emptyset$ nderborg kirkevisitatorium : 203 Betr. die Sonderburger Kirche, Orgel und Organist. Denne pakke rummer originalkontrakten, mens koncept til samme findes i Sønderborg præstearkiv: Sager til den gamle arkivfortegnelse afd. 6 1563-1831. Sager vedr. kirkevæsenet nr. 2, 26 a-b, 36-37.

38. Egen præstearkiv: Ca.5. Bilag til kirkeregnskabet 1768-1800 div. år. Endvidere Egen præstearkiv: Ca.1. Regnskabsbog for uvisse indtægter 1710-84, hvor der fortælles om visse fortrædeligheder under opstillingen; bl. a. forsvandt nogle af piberne, og Angel måtte tage til Flensborg for at fremstille nogle nye.

39. Malerregning fra 1773 (Peter Ebbesen) Egen præstearkiv: Ca.5. Bilag til kirkeregnskabet 1768-1820. Div. år.

40. Egen præstearkiv: Ca.1. Kirkeregnskabsbog, 1667-1742.

41. I den første af de $i$ note 38 nævnte pakker. 
42. Sønderborg præstearkiv: Sager til den gamle arkivfortegnelse afd. 6 1563-1831. Sager vedr. kirkevæsenet nr. 2, $26 \mathrm{a}-\mathrm{b}, 36-37$.

43. Havnbjerg præstearkiv: Ca.2. Kirkeregnskaber med bilag, 17681820 div. ăr. Endvidere Havnbjerg præstearkiv: Ca.1. Kirkeregnskabsbog, $1742-1800$.

44. Augustenborg kirkeinspektorat: Kirkeregnskaber og kirkeregnskabsbilag (Notmark), 1746-1802.

45. De augustenborgske godser, aflevering fra Kiel: C. IV. nr. 126, Ulkeböl, Kirchensachen u. Kirchhof, 1763-1851.

46. C. R. Ebeling startede sin musikalske karriere som lakaj hos hertug Frederik Christian den Aldre på Augustenborg, hvor han var medlem af et hoforkester bestående af tjenerskabet. Se Jens Raben: Fra Als og Sundeved XV s. 50. Vedr. ombygningen af Ulkeb $\emptyset 1$ kirke henvises til Danmarks kirker, Sønderborg amt.

47. Den i note 45 nævnte kilde.

47* Danmarks kirker: København II, s. 111.

48. Niels Friis: Marcussen \& S $\varnothing n$ 1806-1956.

49. Aflevering fra Kiel: C. III. 2. nr, 251. Ulderup.

49* Det må være Nicolai $H$. Angel, som 1810 nævnes i forbindelse med en mindre reparation i S $\varnothing$ derborg. Sønderborg præstearkiv: ba. 3. Kirkeregnskabsbog 1807-21.

50. Egen præstearkiv: Ca.3. Kirkeregnskaber 1799-1924. Under regnskabsåret 1812-13.

51. Havnbjerg præstearkiv: Ca. 2. Kirkeregnskaber med bilag, 1768 -1820, div. år. Under regnskabsåret 1812-13.

52. Sottrup præstearkiv: Bd. 5. Sager vedr. kirkebygning og kirkegård, 1783-1876.

53. Egen præstearkiv: Bc. 4. Kopibøger over udgåede skrivelser $1869-89$.

54. Als Nørre Herreds provstearkiv: Sager vedr, Egen sogn 17241876.

55. Egen præstearkiv: Bd. 8. Sager vedr. kirke- og præstegårdsbygning 1741-1919.

55* Als Nørre Herreds kirkeinspektorat: Sager vedr. kirke- og skolevæsenet i Hagenbjerg 1788-1874.

56. Sønderborg amtsarkiv: Sager til Sønderborg og Nordborg amters journal XVI (Kirkesager).

57. Sønderborg byarkiv XIX. Kirke- og skolesager. Sager vedr. kirkebygning og inventar. 